811.163.41'374::371.3"1818“

https://doi.org/10.18485/mks_srpska_slavistika.2018.2.ch36

Зона В. МРКАљ*

Универзитет у Београду

Филолошки факултет

Катедра за српску књижевност са

јужнословенским књижевностима

\title{
ВУКОВ СРПСКИ РЈЕЧНИК У НАСТАВНОМ КОНТЕКСТУ
}

\begin{abstract}
У раду се разматра широки значај Српског рјечника В. С. Караџића у настави српског језика и књижевности, која корелира и с другим школским предметима (попут Историје, Географије итд.). Увидом у значај Предговора Рјечнику (1818), као и у поглавље Српска граматика, шири се и употпуњује рад са ученицима у наставној подобласти Језик. Мада се Рјечник посматра, пре свега, као лексикографско остварење, показује се на који је начин тумачење одредница ове књиге значајно и за наставу књижевности и реализовање различитих методичких поступака и радњи (нпр. мотивисање, читање, локализовање, тумачење непознатих и мање познатих речи и израза). Анализом одабраних појмова истиче се шта све ученици могу да сазнају о прошлости, историји и традицији српског народа; о народним играма, ношњи, празницима. Помоћу задатака за истраживачко читање Рјечника показује се како се поједине одреднице могу довести у везу са народним приповеткама и предањима, којима се поједини појмови у Рјечнику илуструју. Тумачењем Српског рјечника у наставном контексту развијају се опште и међупредметне компетенције за крај средњег образовања.

Кључне речи: Српски рјечник, настава, српски језик, књижевност, истраживачки задаци, методички поступци и радње, међупредметне компетенције, корелација, усмени прозни облици.
\end{abstract}

Циљ овога рада је да истакне различите начине читања и коришћења Српског рјечника (1818) Вука Стефановића Караџића у настави српског језика и књижевности, уз наглашавање јачања међупредметних компетенција ученика, дефинисаних новим документима који доприносе развоју образовног система Републике Србије. Повезивање садржаја који се према програмима наставе и учења обрађују у оквиру различитих школских предмета (Српски језик и књижевност, Историја, Географија, Биологија...) и остваривање наставних циљева, везаних за упознавање ученика са животом нашег народа у прошлости, обичајима, традицијом и фолклором, могуће је остварити управо наставним тумачењем Вуковог Српског рјечника.

"zonamrkalj61@gmail.com 
Српски рјечник (1818) инспирисао је многа наставна проучавања ове вредне књиге. Поједина истраживања на пољу Методике наставе књижевности и српског језика допринела су, у новије време, афирмисању овог великог лексикографског дела у српским основним и средњим школама. Као занимљиве издвајамо: поглавље „Шаљиве народне приче као коментари уз народне пословице и појмове из Вуковог Рјечника” (Мркаљ 2008: 339-350) и студију Миодрага Павловића „Истраживачка наставна обрада Вуковог Рјечника" (2014б: 61-83), у којој аутор, указујући на Караџићеве речнике из 1818. и 1852. објашњава особености Вуковог тумачења речничких чланака. Овај аутор је назначио и важност истраживачких подстицаја намењених ученицима, при чему се истичу различити сегменти оба речника, тематски се обједињују поједине одреднице узете у разматрање, као и њихове стилске особености.

У уџбеничкој апаратури читанки с краја XX и почетком XXI века (за осми разред основне школе и други разред гимназија и средњих стручних школа), налазе се драгоцени радни налози помоћу којих се ученици подстичу да самостално, или уз помоћ наставника, током редовне и додатне наставе претражују и тумаче одреднице Вуковог Рјечника (1818), да упознају друштвене односе и политичке прилике којима је Вук био савременик; сазнају где се налазе и како су добили имена бројни градови, планине, реке; откривају чудесан свет животиња и биљака, које могу судбински да одреде човеков живот; науче правила заборављених игара, ток обреда везаних за обичаје људи у патријархалној заједници итд. Истраживачки задаци који се могу дати ученицима за припрему, тј. за читање и разумевање одабраних одломака из Рјечника, везују се за одабране примере, дате у акредитованим читанкама.

У зависности од тога о ком је узрасту реч, склоп задатака је другачији.

\section{Примери задатака за истраживачко читање у осмом разреду основне школе ${ }^{1}$}

Читајући опис речи Божић, научићеш који су обичаји поштовани у српском народу приликом прославе великог хришћанског празника. Који се од тих обичаја данас поштују? Обрати пажњу на речи: бадњак, чесница, полажајник. Потруди се да протумачиш значење наведених речи из контекста и служећи се личним искуством.

Уочи и размотри шаљиве и ироничне примесе у објашњењима речи: Ђаволак, злогук, клинчорба, корњача. Припреми се да о томе говориш на часу.

Прочитај објашњења речи јеленак и разбој. Забележи данашње значење датих речи. Погледај тумачења ових речи у Речнику српског језика Матице српске (РСЈ 2007). Имај на уму да уместо овог и Вуковог Рјечника, можеш да користиш и Речник српског кьижевног и народног језика (РСАНУ 1959-).

Образложи значења израза који се у Српском рјечнику наводе уз реч „рука”. Сети се још неких. Шта значе изрази „на своју руку” и „ради као без руку”?

\footnotetext{
${ }^{1}$ Овде наведени задаци прате избор речничких лема наведених у Читанц̧и за 8. разред основне школе (Бајић, Мркаљ 2010: 23-26).
} 
Прочитај још једном епску песму „Диоба Јакшића”, обрађену у седмом разреду, и размотри значај молитвене чаше коју је Анђелија употребила да помири браћу Дмитра и Богдана.

Уз реч „клис” прочитај из Рјечника како су се некад играле дечје игре купа и провођач. Који су данашњи називи игара којих се деца играју у дворишту или у парку? Опиши их.

Размотри тумачења која Вук Караџић даје уз речи Дечани и Котор. Шта све сазнајеш из ових објашњења? Зашто је, по твом мишљењу, Вук користио народна предања да би објаснио наведене речи? Пронађи и прочитај предање о постанку Цариграда.

Прочитај у Рјечнику шта значи реч златоје, а затим се подсети значења речи дјевер и кум. Наброј и напиши што више речи којима се данас означавају родбинске везе. Притом се посебно распитај ко су: заова, јетрва, нећак, шурак и паменог.

Примери задатака за истраживачко читање Вуковог Предговора Српском рјечнику (1818) у другом разреду средње школе

Запази снагу и утемељеност Вукових ставова у тексту овога предговора. Проучи главне стилске квалитете његовог текста: прегледност, разложност и систематичност у изношењу мишљења.

Како је Вук приказао и протумачио чињеницу да Срби хиљаду година имају слова и писмо, а немају свој прави језик? Кога је означио као свог претходника у реформи језика и правописа? Шта важно Доситеј Обрадовић и његови следбеници нису схватили да је потребно учинити по питању реформе језика? Образложи шта значи писати „по правилима баба Смиљане”.

Шта су главни узроци компликованог стања у српском језику које је Вук затекао на почетку 19. века? Зашто је школовање Срба на страним језицима узрок забуне до које је дошло у српској писмености? Којим се језицима служе српски писци Вуковог доба? Зашто неки одбацују народни језик? Каква решења језичких питања су писци нудили? У чему сви они, према Вуковом суду, греше? Који језик Вук сматра добром основом за стварање књижевног језика? Како је он образложио ова гледишта?

Какав став Вук има према ортографији српског језика? Која је нова слова унео у азбуку? Проучи на који начин је образложио увођење слова J из латиничног писма.

Реформа српског језика и правописа је централни део Вуковог рада и кључни напор његових стваралачких активности. Више нападан и осуђиван, него подржаван и подстицан од савременика, Вук никада није посустајао. Запази и тумачи делове текста који сведоче о његовој марљивости, упорности и оптимизму. Зашто су ове Вукове карактерне особине важне за активности којима се бавио? Шта оне сведоче о великим прегаоцима и њиховим делима? 


\section{Примери задатака за истраживачко читање одабраних одредница из Српског рјечника у другом разреду средње школе ${ }^{2}$}

Запази делове текстова које је Вук обликовао на уметнички начин. На којим местима уочаваш кратке форме усмене прозе?

Како народни колектив доживљава и слави божићне празнике? Запази чему се у народу током Божића придаје посебан значај. Протумачи исказе и обредне радње (понашање) којима се током празничних дана подстичу доживљаји мира, радости, заједништва, благородности и жеље за бољим животом. Шта се жели остварити, односно постићи описаним радњама и речима које их прате? Због чега се пажња током празника посвећује животињама и биљкама? Колико се божићни обреди, описани у Рјечнику, разликују од данашњих, а колико су им блиски? Зашто Вук приказује начин божићног обредовања у различитим крајевима?

Издвој елементе анегдоте у одредници хајдук. Проучи који део ове одреднице се развија у приповедачком смислу. Која ти сазнања о хајдуцима и хајдучији доноси овај текст? У којим деловима тог текста је Вук испољио научну објективност? Опиши морал хајдука. Прикажи шта се о начину хајдуковања, односно о животу и ратовању важно дознаје. Зашто Турци окрутно кажњавају хајдуке? Протумачи запажања о храбрости хајдука коју опевају народне епске песме. У ком делу текста се аутор појављује у улози сведока? Проучи и прокоментариши какву улогу имају епизоде чији су актери Михаил Шошо и Станко Црнобарац.

Које важне ставове и драгоцене историјске чињенице доноси текст уз одредницу школа? Установи и објасни какав значај за историју школе и школства у Србији има ова одредница. Процени квалитет школа у Србији Вуковог времена. Шта је, према твом суду, у овим школама било лоше? Шта мислиш, који су узроци таквог стања у тадашњем школству?

Вуков Српски рјечник из 1818. представља неисцрпан извор различитих знања која би ваљало да генерације ученика стекну, уз поуздано наставничко вођење. Мада се Рјечник посматра, пре свега, као лексикографско остварење, у школи се његов садржај мора разматрати знатно шире. На почетку наставног рада важно је ученицима објаснити контекст у којем је ова књига настала ${ }^{3}$. У том смислу можемо се

\footnotetext{
${ }^{2}$ Овде наведени задаци прате избор речничких лема наведених у Читанци за други разред гимназија и средюих стручних школа (Павловић 2014a: 107-114).

${ }^{3}$ Ученицима ћемо посебно истаћи да је Вук Караџић тек у другој књизи народних лирских песама, у „Народној србској пјеснарици”, објавио песме на народном језику, а да је до тада у језик народних песама уносио славеносрпске речи. Пишући и читајући дуги низ година на славеносрпском и црквенословенском, Караџић је тек 1818. године написао чистим народним језиком предговор и тумачење појединих речи у свом Српском рјечнику. Скуп од 27.270 речи представља речник говорног језика Вуковог краја, пропуштен кроз језичко осећање даровитог писца и научника. Богат етнографски материјал, дат као тумачења уз поједине речи открива духовну физиономију патријархалне средине из које је Вук потекао. Ратарско-сточарска и занатско-војничка лексика, као и зачеци правне и културне терминологије, речи које се употребљавају само у усменом песништву чине овај речник јединственим и посебним за сва времена, мада је стваран по угледу на речник новогрчког језика који је почео да излази у Цариграду 1815. Оштар сукоб измеђуВука и Копитара на једној страни и митрополита Стратимировића на другој, као и забрана штампања речника изван Будимске штампарије, довела је до штампања Српског рјечника у Бечу, у штампарији мехитариста (јерменски калуђерски ред). Мехитаристи су имали царску привилегију да могу штампати књиге на свим источним језицима, међу које је, по ондашњим критеријумима, спадао и српски. Према (Поповић 1975: 56).
} 
послужити књигама доступним ученицима у школским библиотекама (на пример, делима Миодрага Поповића или Јована Деретића), као и одломцима из секундарне литературе, датим у читаначким изборима.

Тек након локализовања Српског рјечника у историјски контекст и усвајања значајних информација с тим у вези, ученици могу приступити размишљању о задацима које наставник претходно припреми и уручи ученицима. У зависности од индивидуалних ученичких могућности и интересовања, неки од захтева могу се прилагодити индивидуалном истраживачком раду, који захтева више времена за припрему, или организованом раду групног или фронталног типа, током редовне наставе.

Уколико би се ученици чешће бавили истраживањем значења старих речи и израза и одговоре тражили у речницима српског језика, па и у Вуковом Рјечнику из 1818. године, превазишле би се многе тешкоће у разумевању дела наше народне књижевности за која аутори многих прилагођених издања избора народне књижевности траже пречице, те архаизме замењују њиховим савременим синонимима. Подилажење младим читаоцима у овом смислу не иде на руку развоју њихових читалачких компетенција, бар не онако као то сагледава методика као наука о настави, уважавајући књижевнонаучну методологију.

Као посебно значајне, овде наводимо естетичке компетеничје, које спадају у корпус међупредметних компетенција. Њих ученици треба да стекну до краја средњег образовања. Српски рјечник из 1818. Вука Стефановића Караџића је дело које у настави може вишеструко помоћи усвајању различитих знања и вештина и развијању способности наших ученика.

Пошто је ученик упознат са културним наслеђем људске заједнице, он стиче свест о вредности уметничких и културних дела и њиховог значаја за развој друштва. Постаје свестан значаја естетске димензије у свакодневном животу, има критички однос према употреби и злоупотреби естетике; повезује уметничка и културна дела са историјским, друштвеним и географским контекстом њиховог настанка.

Уз естетичку компетенцију, при читању и тумачењу одабраних одреница из Вуковог Рјечника, посебно се издваја и компетенција решавање проблема, где ученик ангажује своје индивидуалне капацитете (знање из различитих предмета, искуство стечено изван школе, као и интелектуалне, емоционалне и социјалне способности) и друге ресурсе који му стоје на располагању (различити извори информација, књиге, искуство других ученика, наставника и других особа из школског и ваншколског окружења, итд.), селективно и сврсисходно их користи, припремајући се за истраживачки рад на Вуковом Српском рјечнику.

„Развијајући компетенцију сарадюе, ученик је способан да се у сарадњи с другима или као члан групе ангажује на заједничком решавању проблема или на реализацији заједничких пројеката. Учествује у заједничким активностима на конструктиван, одговоран и креативан начин афирмишући дух међусобног поштовања, равноправности, солидарности и сарадње. Активно, аргументовано и конструктивно доприноси раду групе у свим фазама групног рада: формирање групе, формулисање заједничких циљева, усаглашавање у вези са правилима заједничког рада, формулисање оптималног начина за остварење заједничких циљева на основу критичког разматрања различитих предлога, подела улога и дужности, преузимање одговорности за одређене активности, надгледање заједничког рада и усклађивање 
постигнутих договора са новим искуствима и сазнањима до којих се долази током заједничког рада и сарадње. У процесу договарања уме да изрази своја осећања, уверења, ставове и предлоге. Подржава друге да изразе своје погледе, прихвата да су разлике у погледима предност групног рада и поштује друге који имају другачије погледе. У сарадњи с другима залаже се да се одлуке доносе заједнички на основу аргумената и прихваћених правила заједничког рада" (Општи стандарди 2015: 12)4.

Задаци за истраживачко читање Српског рјечника (1818) могу се организовати у више група, према различитим ученичким интересовањима. Они не морају увек бити усмерени ка проширивању знања из српског језика и књижевности, већ се могу односити и на широк спектар функционализованих знања и стицање опште културе.

- Прва група може добити задатак да истражи шта је у Рјечнику записано о празницима који се светкују у нашем народу и обичајима везаним за њих, као и о манастирима, центрима српске културе и духовности.

У том смислу, издвајају се лексеме: Божић, чесница, полажајник, бадњак, Богојављење, Јовањдан, Васкрс, Крсно име, Никољдан, Ђурђевдан, намастир, Дечани, Сопоћани, Студеница, Врдник, Милешева итд.

- Друга група би могла да пронађе називе и описе јела која су се припремала и конзумирала у прошлости.

Књижица рецепата, започета на следећи начин, учинила би функционалним бављење речничким одредницама, чак и ученицима који су се определили за трогодишње средње стручне школе.

ЋУФТЕТА - „Исјеца се ситно пријесно месо и метне се у њега мало бибера и ситно исјецана црна лука, па се онда начине као ораси и умељају се у шенично брашно (и то се зову ћуфтета). Послије тога ћуфтета се попрже на маслу, па се поспу бијелим луком и киселим млијеком” (Караџић 1966: 846)

ЧИМБУР - „Настави се вода у тигању па се посоли; кад вода узаври, онда се на њу разбију јаја, те се читава (не мијешају се) скувају; па се онда вода исциједи и метне се мјесто ње скорупа те се јаја као мало зачине; ђекоји јошт утуку бијелога лука те и залуче” (Исто: 902).

- $\quad$ Tрећа група може тражити речи које данас имају другачије значење него некада, или се другачије изговарају.

На пример, посебно занимљиве ученицима могу бити следеће речи: отмица, старешина, гласати, глад, коб, кокошка, цаба и сл. Наиме, опис обичаја отимања девојке (у случају да се родитељи и родбина успротиве удаји) био је веома ризичан и понекад се завршавао смрћу младожење и батинањем сватова, а свештеник који

\footnotetext{
${ }^{4}$ Општи стандарди постигнућа за крај општег средњег и средњег стручног образовања и васпитања у делу општеобразовних предмета развијани су у периоду од 2010. до 2013. године у оквиру пројекта Министарства просвете, науке и технолошког развоја; Подршка осигурању квалитета система завршних испита на националном нивоу у основном и средњем образовању (ИПА 08) који је финансиран из средстава Европске уније и буџета Републике Србије. (Аутор овог рада, 3. М., била је један од чланова радне групе за израду поменутих стандарда и Приручника за наставнике.)

${ }^{5}$ У даљем навођењу речничких одредница даје се само број параграфа у којем се одредница налази у Српском рјечнику.
} 
би обавио венчање протериван је из службе. Ученичко разумевање речи старешина превазилази Вуково објашњење везано за сеоског и кућног старешину, пошто је њима најближи разредни старешина. Гласати је у Вуково време значило обављати одређену врсту ручног рада; град је представљао тврђаву (утврђење), коб сусрет, кокошка је дугуљаста, шупља основа на коју се намата вуна или конац, те поприма дугуљасти облик, а цаба - џаба ти; на част ти то!

Ученици ове групе могу добити и налог да сачине задатке према следећим моделима, као и да пронађу примере из народних приповедака у којима се поједине речи појављују; на пример - челащ, у причи Лаж за опкладу: „[...] Па ми да и челца, и још пуну торбу проје од изора. Онда ја упртим торбу с пројом на леђа, а седло с пијевца пребацим на челца, те челца узјашем, а пијевца поведем у поводу, да се одмори (Караџић 1969: 16).

a) На линијама напиши синониме за следеће глаголе које проналазиш у Вуковом Српском рјечнику из 1818. године.

Споречкати се (посвађати се); Спотакнути се (саплести се);

Вајкати се (премишљати се, нећкати се).

б) Уместо глагола спазити, у српском можемо употребити глагол (видети/ опазити/уочити).

Уместо глагола умакнути, у српском можемо употребити глагол (обећи).

- Четврта група може се бавити састављањем списка женских и мушких имена, наведених у Рјечнику.

Овде ћемо навести само нека, с почетка азбуке: Аврам, Адам, Алекса, Ацко, Алексија, Алексије, Алемпије, Ана, Анушка, Андра, Андрија, Андријаш, Анђа, Анђелија, Анета, Аница, Анка, Анчица, Анта, Антонија, Антоније, Аранђел, Арса, Арсен, Арсенија, Арсеније, Аца, Вељко, Вера, Верица, Васа, Василија. Василије, Весо, Веселин, Вића, Вићо, Вићентије, Витомир, Витко, Владисав, Влаисав, Влајко, Влатко, Влашко, Вранеш, Гојко итд.

- П Пета група може преписати описе дечјих игара, наведених уз поједине речничке чланке, и добити задатак да те игре изведе.

Анализирањем одредница: банати се, клис, купа и сл. ученици се подстичу да након што проуче игре, њихов ток и смисао, драматизују текст описа игре и припреме га за извођење на позорници, чиме се јачају њихове стваралачке активности.

Овде наводимо игру, описану у коментару речи „помељавити” (Исто: 596):

„Кадшто кад оће деца да забране једно другом говорити, онда једно рече: 'Пун кош жаба, пун кош црви, пун кош гуја (итд.): ко се јави, све да помељави', па већ онда не смију ни једно проговорити.”

- Шеста група би се бавила пописивањем топонима поменутих у Рјечни$\kappa y$, тражила их у географском атласу и поједине уцртавала у нему карту (на пример, Алексинац, Англија, Арнаутска земља (Албанија), Браничево (Пожаревачка нахија), Брачинац, Ваљево, Варадин, Вараждин, Вилиндар (Хиландар), Винковци, Вишеград, Врдник, Градачац, Градишка, Ћуприја, Требевић, Шумадија, Шишатовац, Требишњица, Сарајево итд. 
У корелацији са наставом историје и географије, занимљив материјал за наставно проучавање представља нпр. реч Крајина / Крајина Неготинска (Исто: 333-334). Проучавања оваквог тип откривају не само богате историјске или географске садржаје већ представљају драгоцен извор података о прошлости, територијалном распореду, друштвеном уређењу итд, што је значајно за истраживаче различитог типа.

- Седма група би се могла бавити анализирањем обичаја при свадби, при чему се у наставу може увести и компаративно проучавање лирских народних сватовских песама, или лексиком којом се именује паганско-митска слика живота српског народа. У том смислу, ученици би се припремали да коментаришу речи: вук, вукодлак, вила, вјештица, дружичало, краљице, коледа, додоле, расковник, кукавища, врзино коло... Овде наводимо објашњење које Вук даје уз мање познату реч „стуаћ” (Исто: 801):

„По Ерцеговини приповиједају да се стуаћи (као виле или ђаволи) налазе по великим планинама и по камењацима, и имају на ногама гужве од људскијех жила: да им се ноге не клизају по страни и по камењу; кад се коме прекине гужва, а он увати човека и извуче му жиле из ногу, те начини другу."

- Осма група имала би задатак да попише и класификује предања која Вук Караџић наводи у Рјечнику: Цариград, Тројан, Милошева скакала, Дечани, корњача, те да их допуни избором предања различитог типа, која ученици могу пронаћи нпр. у књизи Од како се земља охладила, Наде Милошевић-Ђорђевић (1997). Шире о предању као школском штиву ученици могу пронаћи у књизи Наставно проучавање народних приповедака и предања (Мркаљ 2008: 285-295).

- Девета група би издвојила шаљиве приче и анегдоте унете у Рјечник ради илустрације појединих одредница, као и стихове из одабраних шаљивих лирских народних песама, узетих за илустрацију речи.

У свом речнику Вук објашњења у виду шаљивих прича наводи као народно казивање и тиме постиже већу сугестивност, што доприноси веродостојности и потврђује реалистичност догађаја. Ове приче су језгровите. Утисак о динамици приче постиже се одговарајућом организацијом композиционих сегмената, чему доприносе и форме приповедања попут дијалога. У Рјечнику су све приче једноепизодичне и фабула им је типична за реалистичку причу. Сажета је, без описа и дигресија; води право ка поенти.

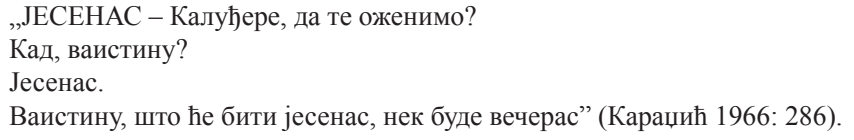

Ученици издвајају и тумаче и објашњења уз речи: ђаволак, дембел, злогук. Посебно им се допадају шаљиве приче о јунацима чији су поступци извори смеха и комике и у којима се исмевају људске мане попут лењости, себичлука, саможивости, глупости... У шаљивој причи се присуство комике подразумева. Може се говорити о два типа комике: вербалној и комици ситуације. У многим примерима из Рјечника 
доминира вербална комика. Пример је прича уз реч „ђаволак” где додетљив поп каже ђаку за девојку да је то ђаволак, а ђак предложи да једног ђаволка поведу у манастир. На комику ситуације наилазимо уз реч „ујам” кад два кума помисле сасвим супротно, видевши да је један од њих воденичар.

На шаљива објашњења у Рјечнику се наилази и потпуно неочекивано. На пример, уз реч „шумнат” (Исто: 927) стоје следећи стихови:

„Мушка глава ко шумната грана:

Удри главом о зелену траву,

Лист опадне, а грана остане.”

Реч „четвртин” (Исто: 900) прати следећа прича:

„Прела баба ноћу уочи четвртка па изашла напоље и у мраку нагазила и узја(х)ала јуне; кад јуне скочи и понесе бабу на себи, онда она стане говорити: 'Господине четвртине! Пусти мене, тебе ће бака светити.' Она је мислила да је носи четвртак: што преде уочи њега.”

Примеса шаљивог запажа се и уз објашњење речи „верати се”. За разлику од данашњег значења, некадашње је било: крити се, провлачити се. Тумачење је у Рјечнику пропраћено шаљивим стиховима:

„Не чудим се лији ни ђердану,

Већ се чудим зецу и гаћама:

Кад се вере, како не издере" (Исто: 65).

Ученицима су смешни и стихови који прате објашњење речи „шићар”:

„У бећара свакога шићара,

Понајвише буа (бува) и ушију (вашака)" (Исто: 918).

- Десета група може сачинити избор народних веровања, као и попис кратких фолклорних форми (питалица, пословица, загонетки, брзалица, изрека, благослова, клетви итд.).

Овде издвајамо само неке од њих:

Веровања: ЋИРИЛ ФИЛОСОФ „Срби приповиједају да тице на Ћирилов дан траже друга свака себи да граде гнијездо и да носе јаја; па која не нађе друга, она се објеси" (841).

ШТУЦАТИ „Кад се коме штуца, онда кажу да га неко помиње; а кад погоди ко га помиње, онда штуцање престане” (Исто: 925).

ЧАБАР „У нашега чабра гвоздене уши (реку жене кад ко приповиједа у кући за какву болест, или за другу какву несрећу, која се ђе догодила” (Исто: 892).

Загонетка: ЦИЦИБАН „Поручује Цицибан Цицибаници: пошљи мене шетљу петљу на магарици; покисе ми бела пена на загалици? (то јест, човек из воденице поручује жени да му пошље кола да носи брашно) (Исто: 888).

Клетва: УЗЈА(Х)АТИ „Да бог да га узја(х)али Турци!” (Исто: 856).

Пословице: Живи као бубрег у лоју, или Ко се (х)вали, тај се квари.

Вуков Рјечник пружа материјал који се може искористити и за проверавање ученичке вештине разумевања прочитаног путем теста, чак и за учење српског језика као нематерњег. 
Задатак за стандард 2.СН.1.3.4. Ученик чита с разумевањем, уз помоћ речника, књижевне, стручне или информативне текстове различитих форми и садржаја.

Прочитај текст Како су се српски војници хранили у Првом светском рату. Уз помоћ информација из текста и Вуковог Рјечника (1818) одреди значења речи које су подвучене.

Иако је аустроугарска војска имала богатије оброке, српски војници су се хранили здравије током Великог рата - употребљавали су таин. И сит и сигуран! То је таин значио за српског војника. Специфична мешавина ражаног и белог брашна могла је да траје дуго и да даје снагу и гипкост у борби. Реч „таин” је турског порекла и значи „следовање”, објашњава Димитрије Вујадиновић, аутор пројекта „Хлеб у Великом рату”. „Наша војска је одмах после турско-српских ратова - почела да производи таин, војни хлеб. Он је био здрав и хранљив. Његови састојци су: 70 одсто ражаног брашна, 30 одсто белог брашна и све се то замеси, не са квасцем већ старим и очврслим, сувим - већ квасним тестом, које се зове комин."

О Вуковом Српском рјечнику из 1818. ученици, према програмима наставе и учења, стичу почетна знања у осмом разреду основне школе, а проширују их у другом разреду средње школе. Притом се остварују многи значајни наставни циљеви (образовни, васпитни и функционални). Овде ћемо навести неке од њих: ${ }^{6}$

- утврдити зашто је прво издање Вуковог речника из 1818. године једна од најзначајнијих књига у историји српске културе;

- анализирати на који начин су у Предговору Српском рјечнику (1818) формулисане основне поставке Вукове језичке и правописне реформе;

- протумачити аргументе које Вук наводи у корист увођења српског народног језика у средиште књижевности и културе;

- анализирати у којој мери се Вукова реченица у описима појединих одредница овог речника ослања на реченицу српске народне прозе;

- упознати се са историјским развојем српског књижевног језика и нагласити допринос Вука Караџића у том смислу;

- препознати основна ортографска решења која Вук примењује у реформи азбуке;

- анализирати Граматику коју је Вук објавио уз Рјечник, која доноси и фонолошки правопис;

- $\quad$ разумети значење Вукове реченице из Предговора Рјечнику, да он није сакупио све српске речи које се говоре у народу, већ је само поставио темељ да се и оне скупе;

- разматрати зашто је учени цензор за словенске књиге Дворске библиотеке у Бечу, врсни филолог Јернеј Копитар, пресудно утицао на идеју објављивања речника, на његову концепцију, као и на превођење речи на немачки и латински језик;

- утврдити од каквог је значаја Вуков Српски рјечник био за своје доба, а од каквог је значаја данас.

Највећи значај Вукових лексикографских творевина из 1818. и 1852. лежи у чињеници да речници представљају синтезу целокупног Караџићевог рада. У њима су заступљене све гране делатности Вука Стефановића Караџића: филологија, ет-

\footnotetext{
${ }^{6}$ Ови наставни циљеви изведени су према радној апаратури из Читанке за други разред гимназија и средњих стручних школа (Сувајџић, Угреновић, Станковић-Шошо 2014: 96-97).
} 
нологија, историја, етимологија, народне умотворине. Управо ова чињеница обезбеђује остваривање бројних наставних корелација (унутарпредметних и међупредметних). Зато је веома важно планирати тематске часове посвећене Српском рјечнику, у чијој ће реализацији, поред ученика, учествовати и наставници различитих школских предмета. Ову потребу поткрепљује и одломак из преписке Јована Ристића ${ }^{7}$ и Вука Стефановића Караџића из давне 1855. године:

„Филозофи, ето вам речника, па тражите у њему скривен ход језика; образујте му тајну и пронађите правила угрожене благогласности његове! Филозофи, ето вам богатства сећања народни - филозофије популарне; откријте нам тајну душе! Судије и учитељи, ето вам књиге, па тражите имена за све што је народу право, што мило, што красно! Певци, ето вам језика ливаде цветне: бирајте цвеће да искитите изливе ваших срдаца српских. Па и ви историци и географи, и сви редом књижевници српски, сви ћете ту наћи доста блага које вам је дојако неприступачно било" (Добрашиновић 1996: 34).

У данашње време, Вуков Српски рјечник доступан је ученицима и у оквиру приређених издања лектире, у којима они могу наћи, прегледно и уз методичко вођење, избор речничких одредница, репрезентативних за стицање комплексних, мултидисциплинарних знања.

Ова капитално Вуково лексикографско дело крије у себи толико богатство, да би се његовом проучавању могла посветити цела школска година, при чему су тематски часови реалнији вид остваривања значајних међупредметних корелација. На наставницима је да све високе вредности Српског рјечника уткају у свест и знање савремених ученика и тако укажу на значај повезивања младих људи са традицијом, обичајима и фолклором нашег народа.

\section{Лuтература}

Бајић Љ., Мркаљ 3. Читанка за 8. разред основне школе. - 1. изд. Београд: Завод за уџбенике, 2010.

Добрашиновић Г. Вук Стефановић Караиић, Преписка XI, 1855-1858. Београд, 1996. Караџић В. С. Српски рјечник (1818). Сабрана дела Вука Стефановића Караџића. Приредио Павле Ивић. Београд: Просвета, 1966.

Караџић В. С. Српске народне приповијетке. Дела Вука Караџића. Приредио др Мирослав Пантић. Београд: Просвета, 1969.

Милошевић-Ђорђевић Н. Од како се земља охладила. Београд: Завод за уџбенике и наставна средства, 1997.

Мркаљ 3. Наставно проучавање народних приповедака и предања. - 1. изд. Београд: Друштво за српски језик и књижевност Србије, 2008.

Опити стандарди постигнућа за крај опитег средњег и средњег стручног образовања и васпитања у делу општеобразовних предмета за предмет Српски језик и књижевност. Приручник за наставнике. Београд: Завод за вредновање образовања и васпитања, 2015.

\footnotetext{
${ }^{7}$ Угледни политичар, државник и историчар. Уз Илију Гарашанина и Николу Пашића спада у ред највећих државника Србије 19. века.
} 
Павловић М. Читанка за други разред гимназија и средюих стручних школа. Уредила Зона Мркаљ (након смрти аутора). Прво издање. Београд: Klett, 2014a.

Павловић М. Спреми се да говориш. Приредили проф. др Зона Мркаљ и проф. др Бошко Сувајџић. Прво издање. Београд: Друштво за српски језик и књижевност Србије, 2014б.

Поповић М. Романтизам. - књ. 1. Београд: Нолит, 1975.

РСАНУ: Речник српскохрватског књижевног и народног језика САНУ, I-XVIII. Београд: Српска академија наука и уметности - Институт за српски језик, 1959-.

PCJ: Речник српскога језика. Нови Сад: Матица српска, 2007.

Сувајџић Б, Угреновић А., Станковић-Шошо Н. Читанка за други разред гимназија и средњих стручних школа. Прво издање. Београд: Нови Логос, 2014.

\author{
Zona V. Mrkalj \\ SERBIAN DICTIONARY BY VUK STEFANOVIC KARADZIC IN THE TEACHING \\ CONTEXT
}

Summary

The paper discusses the wide importance of the Serbian vocabulary V.S.Karadzica in teaching Serbian language and literature, which correlates well with other school subjects (such as history, geography, etc.). After examining the significance of the Foreword of the Glossary (1818), as well as in the chapter Serbian grammar, expands and completes work with students in the teaching of an area of sub-language.

Although the Dictionary is primarily seen as a lexicographic achievement, it is shown how the interpretation of the terms of this book is important for the teaching of literature and the implementation of various methodical procedures and actions (e.g. motivation, reading, localization, interpretation of unknown and lesser known words and expressions).

By analyzing the selected concepts, it is emphasized what all students can learn about the past, history and tradition of the Serbian people; about national games, costumes, holidays. Using the vocabulary for research exploration, it is shown how individual items can be linked to folk tales and lectures, which illustrate certain terms in the Dictionary. Consideration of the Serbian vocabulary in the teaching context encourages the adoption and interdisciplinary competences of the general standards of learning for the end of secondary education.

Key words: Serbian dictionary, teaching, Serbian language, literature, research tasks, methodical procedures and actions amongst subject competencies, correlation, oral prose. 